\title{
Bergson ja naurun yhteisöllinen jännite
}

\author{
JULIUS TELIVUO
}

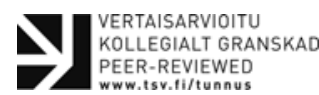

\begin{abstract}
ABSTRAKTı Artikkelissa selvitetään Henri Bergsonin nauruteoriaa teoksessa Nauru ja arvioidaan sen merkitystä osana Bergsonin filosofiaa yleisemmin. Lisäksi artikkelissa täydennetään Bergsonin nauruteoriaa Gilles Deleuzen, Baruch Spinozan ja Friedrich Nietzschen ajatusten pohjalta. Bergson analysoi teoksessa komiikan synnyttämää naurua ja näkee tämän elämän reaktiona sitä kangistavia taipumuksia vastaan. Elämän luovan mukautumisen ja sen kangistumisen välisestä jännitteestä käytetään artikkelissa nimitystä "koominen jännite". Nauru on Bergsonin mukaan olennaisesti inhimillinen ja yhteisöllinen ilmiö, joka huomauttaa jäsenilleen yhteisön elämän kannalta haitallisista poikkeamista. Komiikka on tämän korjaustoiminnon kehittyneempi muoto, ja artikkelissa esitelläänkin myös Bergsonin esteettistä teoriaa. Taiteen tehtävänä on Bergsonin mukaan avata välittömiä näkymiä todellisuuden piirteisiin, jotka jäävät arkisissa havainnoissamme huomaamatta. Komiikalla on myös tällainen paljastava luonne, mutta se on yhteisöllisen korjausliikkeen palveluksessa. Bergsonin nauruteorian omaperäisenä ansiona on sen dynaaminen lähestymistapa komiikkaan, joka tuo esiin naurun yhteisöllisen luonteen. Lähestymistapa on monipuolisempi ja kattavampi kuin useimmat filosofiset ja psykologiset teoriat naurusta ja komiikasta, jotka keskittyvät muodollisiin määritelmiin ja subjektiiviseen kokemukseen. Artikkelissa ehdotetaan kuitenkin kolmea korjausta Bergsonin teoriaan. Teoriaa pitää täydentää komiikan ajoituksen, laajemman naurukäsityksen ja koomisen jännitteen perustavamman merkityksen osalta. Nämä täydennykset pohjautuvat erityisesti Gilles Deleuzen ajatukseen huumorista intensiteettien taiteena. Lisäksi koomisen jännitteen tarkempaa luonnetta kartoitetaan Spinozan ja Nietzschen ajatusten kautta. Spinozan ajattelusta löytyy jäsennys naurun myönteiselle roolille. Nietzsche taas hahmottelee naurulle laajempaa merkitystä, jossa yhdistyvät Bergsonin esteettiset teemat sekä naurun suhde elinvoiman edistämiseen ja rajoittamiseen.
\end{abstract}

Nauru tarttuu välittömästi niin mieleen kuin ruumiiseenkin ja muistuttaa yksilöä yhteisöstään. Näin tehdessään se yhdistää ihmisiä mutta myös eristää nolaten. Naurun sanotaan pidentävän ikää: voisiko naurun ja luovan elinvoimamme välillä olla perustava yhteys? Bergson kysyy teoksensa Nauru (suom. 1994, Le Rire, 1900) aluksi:
Miksei [komiikka] voisi kertoa meille inhimillisen mielikuvituksen työskentelytavoista, sekä erityisesti yhteisöllisestä, jaetusta, kadunmiehen mielikuvituksesta? Kun se kerran on peräisin todellisesta elämästä ja on yhteydessä taiteeseen, niin miksei sillä olisi sanaansa sanottavana elämästä ja taiteesta?” (Bergson 1994,8 , suomennosta muokattu.) 
Bergson löytää naurusta dynamiikan, joka tapahtuu hyvin konkreettisesti ja ruumiillisesti yksilössä mutta kuitenkin olennaisesti myös osana nauravaa yhteisöä. Naurattaessaan komiikka tuo myös välittömästi yhteen luonnon ja kulttuurin. Bergson paikantaa naurun syyn jännitteeseen elämän luovuuden ja sitä kangistavien voimien välillä. Kutsun tätä koomiseksi jännitteeksi. Kuten esitän tarkemmin tuonnempana, Bergson ei kuitenkaan pidä johdonmukaisesti kiinni tämän jännitteen perustavuudesta vaan näkee naurun yhteisöllisen yhtenäisyyden puolustajana. Tämä on nähdäkseni seurausta siitä, että hän loppujen lopuksi liittää naurun liian yksioikoisesti elinvoiman puolustamiseen.

Käsitteellistän koomisen jännitteen ominaista luonnetta tarkemmin Gilles Deleuzen huumoria ja naurua koskevien muotoilujen avulla. Tämä tarkastelu ei niinkään kyseenalaista naurun perustavaa elinvoimaisuutta kuin tuo esiin sen perustavan jännitteisyyden tarkemman ja mutkikkaamman luonteen. Deleuzen huumorikäsitys pohjautuu erityisesti Nietzschen ja Spinozan filosofioihin, joista jälkimmäinen on myös tärkeä taustavaikuttaja Bergsonin ajattelussa. Analyysini tukee Bergsonin perusajatusta naurun luonteesta, mutta kyseenalaistaa hänen nauruun liittämänsä moralismin.

Henri Bergsonin Nauru (Le rire, 1900, suom. 1994) on ranskalaisfilosofin luetuin teos, mutta myös väheksytyin. Teoksen suosio johtuu epäilemättä sen lyhykäisyydestä ja sen helposti lähestyttävästä, arkisesta mutta arvoituksellisesta aiheesta. Suosioonsa nähden Nauru on vähälle akateemiselle huomiolle jäänyt teos, jolle ei uhrata paljon tilaa Bergson-tutkimuksissa. Kirjassa ei kehitetä selkeästi uudenlaista teoriaa ja käsitteistöä toisin kuin Bergsonin kolmessa pääteoksessa, L'Essai sur les données immédiates de la conscience (Tutkielma tietoisuuden välittömistä sisällöistä, 1889), Matière et mémoire (Aine ja muisti, 1896) ja L'Évolution créatrice (Luova evoluutio, 1907). Lisäksi Bergsonin pääteosten aiheet ovat korkealentoisempia ja lähempänä filosofian perinteisiä ydinaiheita: tietoisuus, aika ja avaruus, elävä luonto. Bergson näyttäisi Naurussa lähinnä soveltavan yleistä käsitekehikkoaan jokseenkin mielivaltaisesti valittuun empiiriseen ilmiöön, nauruun.

Bergsonin nauruanalyysin omaperäisyys kuitenkin piilee juuri sen empiirisyydessä. Bergson antautuu aidosti tarkastelemilleen ilmiöille, eikä tyydy vallitsevien käsityksiin ja teorioihin sisältyviin oletuksiin. Hän ei myöskään pakota naurun eri muotoja oman teoriansa raameihin vaan jäljittää komiikan eri muotoja kuin läheistä sukua olevia eläinlajeja, jotka ovat levittäytyneet ja sopeutuneet erilaisiin olosuhteisiin kutakuinkin satunnaisesti. Tästä hajaantumisesta ja eriytymisestä huolimatta lajien käyttäytymisessä ja elintavoissa on edelleen piirteitä, jotka kertovat jaetusta menneisyydestä.

Naurun tarkastelu tuo esiin Bergsonin yleisen filosofisen metodin vahvuuden ja selitysvoiman. Tieteellisen selittämisen perinteinen ihanne on mahdollisimman kattava selityskehikko, jonka erikoistapauksina kaikki yksittäiset ilmiöt voi esittää. Tällaisen mallin vahvuutena on laajaalaisuus, mutta heikkoutena on yhdentekevyys useimpien ilmiöiden kannalta. Esimerkiksi newtonilainen mekaniikka ja myöhemmin vielä suuremmassa määrin Einsteinin suhteellisuusteoria ovat hyvin kattavia teorioita liikkeen ja massan lainalaisuuksista, mutta niillä ei ole paljoa sanottavaa esimerkiksi elävän luonnon ja psyykkisen todellisuuden erityisistä lainalaisuuksista. Bergsonin yleisenä metodina taas on tunnistaa tiettyä ilmiötä ohjaava dynaaminen periaate ja jäljittää sen eri kehityskulut ja haaraumat. Näin hänen tähtäimessään ei edes ole jonkinlainen yleinen esitys todellisuuden luonteesta, lainalaisuuksista ja perimmäisistä olemuksista, vaan tietyn olemassaolevan dynamismin toimintatavan ja variaatioiden selvittäminen. Naurussa tarkasteltava dynamismi on komiikan kehkeytyminen ja eriytyminen eri muotoihinsa.

Naurussa onkin Bergsonin näkökulmasta olennaista sen dynaamisuus: ranskalaisfilosofi ei pyri määrittelemään yksiselitteisesti komiikan ja naurun abstraktia olemusta vaan pikemminkin kartoittamaan sen tunnusomaisia toimintatapoja. Filosofisen analyysin mielenmaisema saattaa tyypillisesti muistuttaa lähinnä anatomista leikkauspöytää, mutta Bergson pyrkii tätä vastoin ha- 
vainnoimaan naurua ja komiikkaa elävinä ilmiöinä luonnollisissa ympäristössään (Bergson 1994, 7, 10-11). Naurun ja koomisuuden luonnollisen elinympäristön tutkiminen ei kuitenkaan tarkoita, että Bergson lähestyisi komiikkaa ainoastaan spontaanina ja eriytymättömänä luonnonilmiönä, joka yksinkertaisesti purskahtaisi esiin tietyissä tilanteissa. Bergson sanookin tutkivansa koomisuuden "valmistusmenetelmiä" (ransk. procédés de fabrication, 2012, v, 156). Tämä tarkoittaa, että hän ei ensisijaisesti erittele ja luokittele komiikan eri muotoja niiden havaittavien piirteiden ja erojen pohjalta, vaan jäsentää komiikan dynaamisia syntymekanismeja.

\section{Nauru ja taide - elämä mekanismin takana}

Pitäisikö Naurun olla hauska kirja onnistuakseen tavoittamaan kohteensa? Bergsonin ensisijaisena päämääränä ei ole yleisön naurattaminen, mutta hän ei myöskään tarkastele neutraalin ja tieteellisen kylmästi kohdettaan ikään kuin ulkopuolelta ja turvallisen etäisyyden päästä.

Nauru kyllä sukeltaa aidosti komiikan ja huumorin maailmaan, mutta komiikan sijaan Bergsonin omana ihanteena on selvästi toinen teoksessa käsitelty inhimillisen toiminnan muoto: taide. Lyhyesti sanottuna taiteen pyrkimyksenä on Bergsonin mukaan saada näkyviin se todellisuus, joka jää huomaamatta rutiinien ja tottumusten keskellä (Bergson 1994, 107-108). Miten tämä todellisuuden peittyminen sitten tapahtuu? Naurua edeltäneessä teoksessaan Matière et mémoire Bergson esittää vakuuttavasti, että havaintomme ja muistimme on ensisijaisesti toiminnan palveluksessa: havaitsemme todellisuudesta useimmiten sen, mikä palvelee jotakin käytännöllistä tarkoitusta ja nämä odotukset ja tottumukset iskostuvat myös hermostomme toimintaan (Bergson 1939, 8, 48-50).

Naurussa Bergson havainnollistaa havaintojen hyötynäkökohtaa esimerkillä suden ja ihmisen havaintojen erilaisuudesta. Susi ei välttämättä erota vuohta lampaasta, sillä kumpikin on sille lähinnä saman kokoinen ja yhtä helppo potentiaalinen makupala (Bergson 1994, 108-109). Vuohi ja lammas taas asemoituvat hyvin eri tavoin inhimillisessä todellisuudessa: esimerkiksi ainoastaan lampaan turkista tehdään villalankaa. Niinpä ihminen on harjaantunut erottamaan lampaan vuohesta, muttei välttämättä yhtä lammasta toisesta, sikäli kuin tällaiselle kyvylle ei ole käyttöä. Bergsonin mukaan suurin osa havainnoistamme perustuu tällaisille totunnaisille rakenteille ja erotteluille, jotka palvelevat jotakin toiminnan muotoa. Havainnon totunnaisuus kuitenkin kätkee ilmiöstä suurimman osan, koska suurin osa todellisuudesta ei näyttäydy ihmisen toiminnan kannalta tähdellisenä ja monesti vain häiritsisi käsillä olevan tehtävän hoitamista.

Bergsonin mukaan juuri tämä kokemuksen ja havainnon havaitsematon ylijäämä muodostaa taiteen keskeisimmän voimavaran. Taide siis tekee havaittavaksi jotakin, mitä emme tavallisesti havaitse. Taiteen esille loihtimat aistimukset ovat peräisin kokemuksen virrasta, mutta niiden epätavallisuus häiritsee jokapäiväisiä havaintojamme ja tekee taiteesta potentiaalisesti pysäyttävää ja jopa kumouksellista (Bergson 1994, 109-115). Taideteosten luomien poikkeavien aistimusten vaikutukset voivat olla hienovaraisia muutoksia kokemusmaailmassamme, mutta esimerkiksi Igor Stravinskyn Kevätuhrin poikkeavat harmoniat saivat yleisön raivoihinsa teoksen kantaesityksessä (Lehrer 2011, 120-123). Pop-taide ja readymade-teokset taas lähtevät liikkeelle juuri tavanomaisista esineistä ja kuvista, jotka kuitenkin esitellään epätavallisessa ympäristössä. Niinpä tällaiset taideteokset on ensinnäkin irrotettu tavallisesta viitekehyksestään, mutta lisäksi juuri niiden arkisuus riitelee myös taidenäyttelyn viitekehyksen kanssa.

Ajatus taiteesta eräänlaisena poikkeavana havaitsemisen tapahtumana tuo yhteen eri taiteet säilyttäen kuitenkin niiden kunkin erityisyyden. Bergson tuo esiin aistien moninaisuuden eri taiteiden yhtenä perustana: musiikki voi irrottaa kuulon arkirutiineistaan ja maalaus näön (Bergson 1994, 110-111). On useimmiten keinotekoista etsiä muodollisia yhtäläisyyksiä esimerkiksi sävellysten ja kuvataideteosten välillä, mutta teosten vaikutusten näkökulmasta kumpikin selvästikin tuo kokemuksen piiriin epätavallisia aistimuksia, ainoastaan eri aistien ja kokemuspiirien kautta. 
Bergsonille taiteen epätavanomaisuus ei kuitenkaan ensisijaisesti tarkoita surrealismia tai erikoisuuden tavoittelua vaan eräänlaista äärirealismia tai -empirismiä, jossa taiteilija vangitsee teokseensa arkikokemukselta pakenevia aistimuksia. Bergsonilaisin taidemaalari lieneekin Paul Cézanne, jonka erityisenä metodina oli tuijottaa näkymää niin kauan, että sen hahmot alkoivat menettää totunnaisia rajojaan ja muotojaan jättäen jäljelle vain värejä ja varjoja (Lehrer 2011, 102).

Mutta miksi Bergson pohtii taiteen olemusta teoksessa, jonka aiheena on nauru? Hän päätyy näihin pohdintoihin komedian kautta, mutta onko komedia edes taidetta? Komedia toimii toki taiteen yleisen pyrkimyksen mukaisesti sikäli, että se tuo esiin uusia puolia todellisuudesta, Bergsonin mukaan lähinnä ihmisten jäykkiä ja kömpelöitä piirteitä. Nauru ei olekaan Bergsonille pelkkä komedian ilahduttava sivutuote tai arvostuksen osoitus vaan komedia on pikemminkin naurun palveluksessa. Naurun tehtävänä on Bergsonin mukaan nimittäin paljastaa ja suitsia jäykkiä ja kankeita taipumuksia ihmisen toiminnassa, ja tämä on Bergsonin mukaan myös komedian perimmäinen päämäärä. Mutta toisin kuin muilla taiteilla, komedialla ja komiikalla yleisemmin on vahva yhteisöllinen funktio: oikaista haitallista, yhteisön elinvoimaa heikentävää poikkeavuutta. Tämä vähentää Bergsonin silmissä komiikan taiteellista arvokkuutta ja tekee siitä muutenkin kyseenalaisempaa: pilkan kirveellä on pohjimmiltaan hyvä tarkoitus, mutta se myös huitoo sen kummemmin miettimättä. Toisinaan se paljastaa todellista kankeutta ja jämähtäneisyyttä, mutta usein pelkkä poikkeavuus riittää tekemään asian naurunalaiseksi.

Kai Alhasen mukaan Bergson sijoittaakin filosofian taiteen ja komiikan väliin: "nauru havahduttaa filosofin tehtäväänsä, jossa taide voi näyttää suuntaa" (Alhanen 2010, 233). Filosofia pyrkii taiteen tavoin näkemään tarkemmin kuin arkikokemus, mutta taiteesta poiketen se myös ottaa suoraan kantaa arkikokemuksen käsityksiin. Komiikan ja naurun tavoin filosofia taas puuttuu jähmettyneisiin tapoihin ja käsityksiin, mutta se ei tyydy välittömään korjausliikkeeseen ja nolaamiseen vaan pyrkii tuomaan epäkohdan luonteen ja syyt esiin perusteellisemmin, ajattelemalla ja ajatteluun vetoamalla.

\section{Yhdessä nauraen jäykistymistä vastaan}

Bergson kohdistaa teoksessaan huomionsa nimenomaan komiikan kirvoittamaan nauruun, ja komiikan ytimenä on hänen mukaansa jäykkyys ja kankeus, jotka rajoittavat elämän luovuutta ja joustavuutta. Naurun kohteena ja komiikan perusaineksena on "elollista kahlitseva mekaanisuus" ("du mécanique plaqué sur du vivant", Bergson 1994, 31, 39, 44). Tämä ei kuitenkaan ole Bergsonin mukaan niinkään koomisuuden määritelmä tai olemus kuin johtoaihe, leitmotiv, joka säestää kaikkia koomisuuden muotoja ja resonoi niiden kanssa (mt. 20).

Bergsonin mukaan koominen mekaanisuus ensinnäkin lähentää ihmistä elottomaan luontoon: "Mutta joustamattomuuden, epähuomion tai ruumiin taipumattomuuden vuoksi, seurauksena jäykkyydestä tai saavutetusta nopeudesta, lihakset jatkoivat samaa liikettä, vaikka olosuhteet vaativat muuta" (mt. 12). Bergsonin muotoilut tuovatkin mieleen Newtonin muotoileman mekaniikan 1. lain: "Kappale jatkaa tasaista suoraviivaista liikettä vakionopeudella tai pysyy levossa, jos siihen ei vaikuta ulkoisia voimia”. Bergsonin yleinen malli koomiselle hahmolle on sätkynukke, joka toimii kaikissa tilanteissa konemaisesti eikä kykene itse ohjaamaan omaa toimintaansa. Yleisemmin komiikkaa luonnehtii siis mekaaninen väkinäisyys, tapojen orjuus, toisto. Nykyään Bergson puhuisi epäilemättä roboteista. Tosin robotit ovat jo hyvän aikaa näyttäytyneet populaarikulttuurissa myös uhkaavina hahmoina. Kuten Bergson toteaa, nauru kertoo myös siitä, että elämää kangistava mekanismi ei haitallisuudestaan huolimatta tunnu uhkaavalta. Samaten zombit voivat tilanteesta riippuen näyttäytyä kammottavina tai koomisina.

Koominen mekaanisuus ei kuitenkaan rajoitu fyysiseen kaatuiluun ja törmäilyyn vaan saa hyvin erilaisia, yllättäviäkin muotoja: ulkomuoto, ilmeet, liikkeet, tilanteet, kieli, luoteenpiirteet. Esimerkiksi kielellisessä komiikassa, kuten Théodore Barrièren näytelmässä Faux bonshommes: "Ystävä 
hyvä, pörssi on vaarallista peliä. Yhtenä päivänä voittaa, toisena häviää. - Mikäs siinä, sitten pelaan vain joka toinen päivä." (Mt. 84.)

Nauru on siis tietyllä tapaa elinvoimainen purskahdus, joka paljastaa elämää jähmettävän kankeuden, mutta Bergson ei tästä huolimatta ilmoittaudu sen varauksettomaksi kannattajaksi. Tämä on sikäli merkille pantavaa, että Bergsonin teosten yksi keskeinen pyrkimys on elämän luovuutta ja mukautuvuutta kahlitsevien taipumusten tunnistaminen ja vastustaminen. Perustavimmassa muodossa hän muotoilee tämän kamppailun luovuuden ja kankeuden välillä ajallisen keston (durée) ja tilallisuuden välisenä jännitteenä. Meillä on taipumus jäsentää kaikenlaiset ilmiöt tilallisina ja antaa elävän keston näkökulman jäädä tämän tilallisen kuvauksen varjoon. Esimerkiksi työaikaa hallinnoidaan homogeenisenä kvantiteettina, eikä hetki hetkeltä kehittyvänä ja avautuvana prosessina.

Bergsonin esikoisteos L'Essai (1889) lähestyy tätä joustavuuden ja jäykistymisen välistä jännitettä lähinnä yksilöllisen inhimillisen kokemuksen näkökulmasta. Tässä teoksessa Bergson pyrkii osoittamaan, kuinka kokemuksen ajallisuutta jäsentävät tilalliset mallit ja metaforat johtavat epäjohdonmukaisuuksiin ja hämärtävät keston luonteen. Esimerkiksi sävelkulun kuuleminen muodostaa Bergsonin mukaan laadullisen kokonaisuuden tai keston, jota ei voi jakaa pienempiin osiin muuttamatta sen ominaisluonnetta. Sävelkulku kyllä muodostuu pienemmistä osista, mutta ne kytkeytyvät toisiinsa ja sävelkulun kokonaisuuteen erottamattomammin kuin ulottuvaiset osat. Ajan jakaminen homogeenisiin yksiköihin ja sävelkulun esittäminen paperille levitettynä nuottien jonona luovat illuusion diskreetistä kokonaisuudesta, joka koostuu erillisistä yksiköistä.

Teoksessa Matière et mémoire Bergson avaa inhimillistä kokemusta yksilön näkökulmasta yleisempään, epäpersoonalliseen suuntaan (Bergson 1939, 30, 45; vrt. Deleuze 2018, 18-23). Todellisuutta ei nimittäin lähestytä siinä enää yksilön kokemuksen näkökulmasta, vaan todellisuus koostuu kuvista, jotka kattavat kaikki todellisuuden osat sikäli kuin ne ovat vuorovaikutuksessa toistensa kanssa. Vastaavasti muisti ei Bergsonin mukaan ole jonkinlainen subjektiivisten kokemusten säiliö vaan se on olennaisesti kyky, joka kehittyy vuorovaikutuksessa ulkomaailman kanssa ja sen päätehtävänä on mahdollistaa joustava toiminta ympäristön vaihtelevissa tilanteissa.

Nauru taas ennakoi teoksen Évolution créatrice (1907) evolutiivista näkökulmaa, jossa elämän kehityssuuntana on ärsykkeisiin reagoimisen löyhentyminen ja vastaavasti kehittyneimpien elämänmuotojen toimintamahdollisuuksien moninaistuminen. Voisi siis kuvitella, että Bergson näkisi kangistumisesta ja taantumisesta huomauttelevan naurun olennaisesti elämänmyönteisenä voimana. Naurun elinvoimaisuutta kuitenkin vääristää hänen mukaansa se, että se on olennaisesti ihmisyhteisön kanavoimaa. Toisin sanoen nauru ei ole puhtaan luonnollinen, yksilöllinen reaktio elämää jäykistäviin voimiin vaan se on olennaisesti inhimillinen, kulttuurillinen ja yhteisöllinen, tietyn ryhmän sisäinen ilmiö. Ihmisyhteisö nauraa jäsenelleen, joka toimii liian kaavamaisesti kykenemättä sopeutumaan erilaisten tilanteiden tarkkoihin edellytyksiin (Bergson 1994, 10-12). Ihmiselle on luonteenomaista ja lajityypillistä arvioida toimintaansa ja sen vaihtoehtoja muita lajeja monipuolisemmin, ja nauru voi ilmentää melko hienovaraistakin ymmärrystä havaitusta kömpelyydestä. Bergsonin mukaan ongelmana kuitenkin on, että kaiken ihmisen toiminnan tavoin nauru itsekin voi urautua ja siis äityä naurettavaksi.

Naurun ylilyönnit ja haavoittavuus ovat seurausta sen urautumisesta mutta myös sen välittömyydestä - nauru sulkee pois harkinnan ja myös voimakkaat myötätunnon tunteet (mt. 9-10). Emme naura silloin kun tunnemme sääliä ja samastumme johonkuhun varauksetta. Tietyt voimakkaat tunteet epäilemättä riitelevätkin naurun kanssa, mutta kuten osoitan tuonnempana, Bergsonin nauruteoria ei myöskään tarjoa selitystä esimerkiksi voimakasta iloa ilmaisevalle naurulle. Kieltämättä Bergson rajaa tarkastelunsa juuri komiikan aiheuttamaan nauruun, mutta nähdäkseni tämä rajaus ei ole perusteltu. Bergsonin teoriaa on kuitenkin mahdollista täydentää näiltä osin hylkäämättä sen perusoivalluksia.

Naurun yhteisöllisyyteen ja seurallisuuteen on usein kiinnitetty huomiota, mutta tämä piirre kui- 
tenkin loistaa poissaolollaan useimmissa naurua koskevissa teorioissa. Yhteisöllisen ulottuvuuden huomioiminen onkin Bergsonin teorian kiistaton ansio (ks. Kunnas 2017, 12-13; Provine 2000, 16; Prusak 2004). Useimmiten naurua on tutkittu yksilön reaktiona, esimerkiksi Herbert Spencer eräänlaisen hermolatauksen purkautumisena ja Freud tunnepatoutumien vapautumisena. Yhteisöllisestä näkökulmasta filosofit ovat perinteisesti nähneet naurun ilkeämielisen pilkkaamisen muotona ja sikäli paheksuttavana pikemmin kuin yhteisöllisenä siteenä. (ks. Critchley 2002, 2-3; Morreall 2020.) Bergsonkin näkee komiikan ja naurun ytimenä vikojen osoittelun, mutta tämä korjausliike on pohjimmiltaan elämän palveluksessa ja pilkka sekä nolaaminen ovat hänen näkökulmastaan lähinnä komiikan taantuneita sivuvaikutuksia.

Naurun perustavan yhteisöllisyyden huomioiminen tuntuisi olevan välttämätöntä naurun inhimillisten erityispiirteiden selittämiseksi. Evoluutiopsykologiassa huumorintaju esitetään toisinaan älykkyyden ja muunkin ihmiselle tyypillisen kelpoisuuden merkkinä (Greengross 2008; Li ym. 2009; Miller 2001, 415-416). Mutta miksi älykkyys ilmenisi juuri nauruna? Toinen vakuuttavampi teoria korostaa naurun, leikin ja leikkisyyden yhteyttä ja niiden tärkeyttä ihmislapsen yhteisöllisessä kehityksessä. Leikki tarjoaa mahdollisuuden kohdata poikkeuksellisia ja uudenlaisia, mahdollisesti uhkaaviakin tilanteita turvallisessa ympäristössä. Nauru ja hassuttelu taas ovat osa tällaista leikillistä ilmapiiriä, ja nauru erottaa leikkisän tilanteen uhkaavasta (Cohen 1999; Eastman 1936; Morreall 2020.) Leikillisyyden näkökulma on epäilemättä oikean suuntainen, ja se tavoittaa naurun yhteisöllisyyden ja jännitteisyyden. Selitys on kuitenkin ulkokohtainen: miksi leikillinen uhka naurattaa?

Väitän, että naurun yhteisöllisyydessä olennaista on koomisen jännitteen rakentuminen ihmisryhmässä. Miksi tällainen jännite rakentuu pääosin juuri ihmisten keskuudessa ja harvemmin eläinten tai muiden luontokappaleiden seurassa? Vastauksena voisi olla ihmisen kyky hahmottaa hienovarainen, virtuaalinen mahdollisuuksien kirjo toistensa toiminnassa ja myös kyky poiketa yllättäen luontevista tapahtumasarjoista ja huo- mata nämä poikkeamat. Koomisuus perustuu oletukseen ihmisen vapaudesta. Luonto ei ole hauska, koska oletamme sen kulkevan omaa vääjäämätöntä polkuaan. Bergsonin mukaan ihmiset taas ovat huvittavia töppäillessään hajamielisinä, koska he olisivat voineet toimia toisin jos olisivat olleet valppaana. Kuten totesin jo aiemmin, Bergsonille kaikki koomisuus on tavalla tai toisella tahatonta, mutta tahattomuuteen sisältyy mahdollisuus toimia taidokkaasti, ainakin ajatuksen tasolla. Vastaavasti hänen mukaansa koira tai hattu on hauska vain tullessaan osaksi inhimillisen toiminnan piiriä tai muistuttaessaan siitä: koira naurattaa käyttäytyessään ihmismäisesti ja hassu hattu muistuttaa muotoilijansa mielenliikkeistä (Bergson 1994, 8).

Naurun yhteisöllisyyden korostamisessa tärkeää on koomisuuden dynaamisen luonteen esiin tuominen. Komiikka ei ole pohjimmiltaan pelkkä älyllinen harjoitus, jonka voisi toistaa mielivaltaisella hetkellä itsekseen, vaan se levittäytyy tilaan ja tapahtuu siinä tietyn rytmin ja jännitteen mukaisesti. Niinpä naurua ei voi myöskään ymmärtää pelkkänä yksilön psyykkisen tai hermostollisen energian purkautumisena, kuten esimerkiksi Spencer ja Freud ajattelivat. Kaikki komiikka on tilannekomiikkaa. Bergson tuo esiin naurun ja komiikan yhteisöllisyyden mutta typistää naurun kuitenkin yhteisön itsekorjausrefleksiksi. Bergsonin paikantama jännite mukautuvuuden ja jäykkyyden välillä tuntuisi olevan olennainen osa kaikkea naurua, mutta on nähdäkseni perusteetonta olettaa että nauru olisi yksiselitteisesti yhteisön elinvoiman puolella. Nauramme nimittäin myös ilosta, ihailusta ja hämmästyksestä. Ja jos nauru ei ole yhtä selkeän puolueellinen kuin Bergson olettaa, tämä myös hälventää sen merkitystä yhteisen moraalin vahtikoirana. Miten naurun yhteisöllinen jännite sitten rakentuu?

\section{Bergsonin teorian puutteet ja Deleuzen intensiivinen huumori}

Bergson tuo ansiokkaasti esiin naurun yhteisöllisyyden ja dynaamisen luonteen: nauru ei ole pelkkä yksilön mielenliikkeiden hetkellinen ilmaus vaan se syntyy erityisessä yhteisöllisessä tilanteessa. Bergsonin nauruteoriassa on nähdäk- 
seni kuitenkin kolme perustavaa puutetta, jotka kytkeytyvät naurun syntymekanismiin: koomisen ajoituksen keskeisyyden unohtaminen, analyysin rajoittaminen koomiseen nauruun ja koomisen jännitteen tarkasteleminen ainoastaan elinvoimaisuuden puolustamisen näkökulmasta.

Bergson ensiksikin sivuuttaa kysymyksen koomisuuden arvaamattomuudesta. Kuinka näennäisesti sama tilanne voi yhtenä hetkenä olla äärimmäisen koominen ja toisena tuiki tavallinen? Olennainen täsmennys Bergsonin teoriaan löytyy nähdäkseni Gilles Deleuzen filosofiasta. Teoksessaan Différence et répétition (Ero ja toisto, 1968, 315-317, ks. myös 12) Deleuze määrittelee huumorin intensiteettien taiteeksi ja ironian ideoiden taiteeksi. Deleuze viittaa epäilemättä huumoriin ja komiikkaan sisältyvään rytmiin ja jännitteeseen. Huumori tapahtuu välittömästi aistittavalla tasolla tietyn tilanteen ehdoilla. Ironia taas viittaa itsensä ulkopuolelle johonkin, mitä se ilmentää vain osittain ja epäsuorasti.

Deleuzen mukaan komiikka ja traagisuus perustuvat kummatkin toistoon ja tietämättömyyteen. Koominen tietämättömyys koskee jokapäiväisiä asioita, traaginen tietämättömyys puolestaan tavallisen ihmisen käsityskyvyn ylittävää kosmista, "esoteerisia" tietoa (Deleuze 1968, 25). Deleuzekin liittää Bergsonin tavoin koomisuuteen mekaanisen toiston aineksen, joka toimii tilanteessa kuin tilanteessa vanhojen kaavojen pohjalta. Hän kuitenkin näkee toiston perustavana ilmiönä, jonka köyhin muoto mekaaninen toisto vain on. Todellisuus tapahtuu lukemattomina toistuvina prosesseina, joihin kuitenkin kuuluu myös variaatiota ja toisinaan myös perustavia muutoksia. Traagisuuskin näyttäytyy osana toistavaa kehityskulkua, mutta saa aikaan muodonmuutoksen päähenkilössä. Deleuze nimeää dramaattiseksi toiston, joka synnyttää uutta ja jättää päähenkilön taakseen. Uuden synnyttäminen siis edellyttää yksilön näkökulman ylittävien kehityskulkujen liikkeelle panemista. (mt. 121-123.)

Deleuzelle koomisuus ja huumori ovat perustavasti pinnallisia ilmiöitä. Teoksessa Logique du sens (Mielekkyyden logiikka, 1969) hän määritteleekin huumorin uudestaan "pintojen taiteeksi" (Deleuze 1969, 18, 166, 289). Deleuze liit- tää koomisuuden Bergsonin tavoin arkisiin, toistuviin tottumuksiin ja kaavamaisuuksiin, mutta huumorin hän näkee välittömän aistimuksen tason taiteena. Hän kehittää edelleen aiempaa pinnan, syvyyden ja korkeuden erotteluaan kielellisen merkityksellisyyden ja mielekkyyden näkökulmasta, jossa korkeus viittaa kielelliseen merkitykseen, syvyys ruumiin materiaalisuuteen ja pinta taas näiden rajapinnan tapahtumiin ja mielekkyyteen. Kirjan suurimpia humoristeja ovat kenties kyynikot, jotka toimivat kepeästi merkityksen pinnalla: kokemuksen ylle kohoavien merkitysrakennelmien sijaan he tyytyivät osoittelemaan konkreettisia olentoja. Platonin ihmisen määritelmän "höyhenetön kaksijalkainen" kuulleessaan kyynikko-Diogenes vastasi vetämällä toogansa taskusta esiin kynityn kukon (mt. 159).

Myöhemmin Deleuze kuitenkin sanoo hylänneensä tämän pinnan ja syvyyden välisen erottelun (Deleuze 2002, 364). Hän kuitenkin säilyttää välittömän jännitteisyyden näkökulman ajattelussaan ja kuvaa Nietzschen teosten naurua ironian ja huumorin nousujen ja laskujen intensiivisenä vaihteluna (mt. 360).

Bergsonin nauruteorian kannalta kiinnostavinta Deleuzen huumorikäsityksessä on ajatus huumorin välittömästi aistittavasta jännitteisyydestä. Aistimukset ovat Deleuzen mukaan intensiteettejä, jotka näyttäytyvät ja tapahtuvat olennaisesti jännite- ja potentiaalieroina. Deleuze kyseenalaistaa näin kaksi syvään juurtunutta ajatusmallia. Aistimukset eivät ensinnäkään ole jonkinlaisia mielensisältöjä tai olioiden laadullisia ominaisuuksia vaan eroavaisuuksia: intensiteetti on aina intensiteettiero. Toiseksi Deleuze ei tyydy kuvaamaan aistimusta negatiivisena, "ei-identtisenä" tai jonakin abstraktina tai pakenevana, vaan hän luonnehtii intensiteettieroja positiivisina, tuottavina potentiaaleina tai jännitteinä, jotka saavat asiat tapahtumaan ja ilmiöt ilmenemään. (Deleuze 1968, 287, 307, 317)

Bergson ei erikseen mainitse komiikan rytmillistä ja ajallista ulottuvuutta nauruanalyysissaan, vaikka se ilmiselvästi sisältyykin moniin hänen esimerkkeihinsä. Hän ei huomioi tarkan ajoituksen merkitystä, jonka myötä tilanteesta tulee koominen tai jonka ansiosta koomikko saa yleisönsä 
nauramaan. Ollakseen hauska joustavuuden ja jäykkyyden välisen jännitteen pitää lisäksi ilmetä ja purkautua yllättäen ja äkkiä. Kaikki vitsit voi vesittää venyttämällä huipennusta riittävän kauan ja vastaavasti taitavakin ajoitus voi epäonnistua jos yleisö on väärässä mielentilassa.

Vaikka Bergson ei huomioi huumorin rytmitystä ja ajallisuutta riittävän tarkasti, hänen näkökulmansa komiikkaan ja sen mekaanisuuteen on kyllä perustavan dynaaminen. Tämä selittää sen, että hän ottaa komiikan rytmityksen ikään kuin annettuna: elämä kulkee omaa joustavaa rytmiään, jonka komiikka rikkoo väkinäisyyksillään, liioitteluillaan ja sopimattomuuksillaan. Kuitenkin komiikan vaikutus perustuu selvästi juuri tähän elämän joustavaan pohjavireeseen, jota vasten se asettuu. Elämä on Bergsonille luovaa ja mukautuvaa liikettä, jonka jäykistymisestä ja kangistumisesta nauru varoittaa.

Komiikka perustuu Bergsonin mukaan aina tälle joustavuuden ja jäykkyyden väliselle jännitteelle ja dynamiikalle, mutta olennaisesti tahattomasti. Koomisessa jäykkyydessä on erityisen jäykkää ja koomista se, ettei henkilö itse havaitse tilanteen koomisuutta. Bergsonin mukaan ymmärtämättömyys, ulalla oleminen ja hajamielisyys ovat itse asiassa koomisuuden inhimillisessä ytimessä. Tietoisuus ja äly ovat ihmisen kehittynein ja tehokkain tapa sopeutua elämän haasteisiin, joten niiden puute tarjoaa rikkaan maaperän komiikalle. Komiikassa yhdistyvätkin unen ja koneen maailma, jotka ovat inhimillisen todellisuuden kaksi ääripäätä: uni on puhdasta henkistä todellisuutta, ja mekanismi taas puhtaan materiaalista toimintaa. Uneksija on koominen käytännön toiminnan näkökulmasta ja mekaaninen laite taas erilaisiin tilanteisiin mukautuvan luovan älykkyyden näkökulmasta. (Jankélévitch 1959, 124.)

Deleuze esittää Cinéma 2 -teoksessaan (1985), että erityisesti Jerry Lewisin burleski-komediat eivät enää mahtuisi Bergsonin mekaaniseen komiikkakäsitykseen. Aiemmat burleskin elokuvan muodot perustuivat hahmojen sensorimotorisuudelle eli ruumiinliikkeiden ja havaintojen yhteispelille joko toiminnan (Buster Keaton, Charlie Chaplin), puheen tai jopa ajattelun tasolla (Groucho Marx, äänielokuvien Chaplin). Lewisin elokuvissa taas syntyy puhtaan optisia ja äänellisiä kohtauksia, joissa tilanteet, rekvisiitta, elektroniset ja itseohjautuvat laitteet alkavat elää omaa elämäänsä, vieden hahmot mukanaan. Näiden kohtausten koko maailma värähtelee kuin sähköverkko, johon hahmot kytkeytyvät. "Koomisuus ei enää ole elollista kahlitsevaa mekaanisuutta vaan maailman liikettä, joka tempaa ja imaisee elollisen mukaansa" (Deleuze 1985, 89). Deleuzen ehdottama päivitys Bergsonin teoriaan kuitenkin koskee ensisijaisesti koomisuutta koskevaa muotoilua ja siihen liittyviä mielikuvia ja teknisiä hahmoja, eikä niinkään Bergsonin perusajatusta naurun syystä. Deleuzen mukaan komiikka ei rajoitu ihmisyksilön toiminnan mekaanisuuteen vaan koominen jännite voi vallata tilanteen ja ympäristön eräänlaisen aaltoliikkeen tavoin. Ajatus komiikasta jonkinlaisen väliaineen tai kentän toimintana tuntuisi myös tukevan esittämääni ajatusta koomisesta jännitteestä naurun lähteenä. (mt. 87-91.)

Bergsonin nauruteorian toisena pääpuutteena on nähdäkseni sen rajoittuminen komiikan herättämään nauruun. Tämä on toki Bergsonin itsensä valitsema rajaus, mutta se hämärtää naurun yleisempää luonnetta ja merkitystä. Koomiseen nauruun keskittymisen rajoituksena on se, että Bergson tarkastelee vain osaa naurun luonnollisesta elinympäristöstä. Päteekö koomisen naurun yhteisöllisen roolin analyysi muuhun nauruun ja millä perusteella? Mikäli koominen nauru taas eroaa perustavasti muusta naurusta - esimerkiksi vaivautuneesta ja innostuneesta - niin mikä selittää reaktioiden samankaltaisuuden?

Vaikka Bergsonin analyysi rajautuu koomiseen nauruun eikä nauruun yleensä, hän joka tapauksessa tavoittaa suuren osan naurun eri muodoista keskittymällä yhteisölliseen tapahtumiseen sen sijaan, että pyrkisi määrittelemään koomisuuden abstraktin olemuksen, esimerkiksi teoksen ominaisuutena tai katsojan mielenliikkeinä. Bergsonin omaksuma näkökulma mahdollistaa komiikan ja naurun tarkastelemisen konkreettisesti, tietyssä ympäristössä ja yhteisössä tapahtuvana ilmiönä. Hän myös tunnistaa naurun inhimillisen erityisluonteen. Tosin eräät muutkin nisäkkäät osaavat jossain mielessä nauraa - lähinnä ihmisapinat, koirat, hyeenat, rotat ja del- 
fiinit. Todennäköisesti naurulla ei kuitenkaan ole yhtä merkittävää ja monimuotoista paikkaa näiden nisäkkäiden elämässä kuin inhimillisessä todellisuudessa. Vaikuttaisi myöskin selvältä, ettei ihmisen nauru ole pelkkä spontaani, yleisinhimillinen selkäydinrefleksi. Naurutottumukset nimittäin vaihtelevat eri ihmisryhmien välillä, mikä viittaisi siihen, että komiikassa on vahva kulttuurillinen, opittu ulottuvuus. Tästä kertoo jo komiikan vahva kietoutuminen kielelliseen ilmaisuun. Toisin sanoen nauru on tunnistettavasti inhimillinen ilmiö, mutta ihmiselläkään se ei ole yleismaailmallista ja tässä mielessä rajaudu lajityypilliseen käyttäytymiseen.

Bergsonin teorian kolmas peruspuute on se, että hän valjastaa naurun luovuuden puolelle kankeutta vastaan. Hänen omassakin analyysissaan käy ilmi, että nauru voi rutinoitua ja näin menettää elämän luovuutta mukailevan luonteensa. Tämä on olennaisesti seurausta siitä, että naurukulttuuri kehittyy osana ihmisyhteisön yhteiseloa, jolloin se varoittaa sopeutumattomasta jäykkyydestä ensisijaisesti suhteessa yhteisöön ja sen normeihin eikä yleisemmin suhteessa elämään ja luontoon. Lisäksi nauru reagoi pinnallisesti välittömiin vaikutelmiin ja mielleyhtymiin, ja Bergson osoittaa vakuuttavasti, että melkein mikä tahansa poikkeama voidaan mielleyhtymien välityksellä saattaa naurunalaiseksi. Tästä huolimatta Bergson näkee naurun ensisijaisesti elämän itsepuolustuskeinona, ja naurun rutinoitumisen jonkinlaisena taantumisena ja naurun alkuperäisen tehtävän hämärtymisenä, jota voi korjata ainoastaan älyllisen harkinnan kautta.

\footnotetext{
Osuakseen aina oikeaan naurun tulisi perustua harkintaan. Mutta nauru on vain seurausta mekanismista, jonka luonto on virittänyt meissä, tai tarkemmin ottaen pitkä kokemus elämästä yhteisössä. Nauru sivaltaa kuin itsestään, viipyilemättä. Se ei ehdi katsoa joka kerta, mihin se osuu. (Bergson 1994, 138-139, suomennosta muokattu.)
}

Nauru itsekin on siis Bergsonin mukaan mekanismi. Astesiano (2016, 338; vrt. Sibertin-Blanc 2011, 66) tuo esiin Bergsonin nauruanalyysin yhteyden tämän myöhempään teokseen Les Deux
Sources de la morale et de la religion (Moraalin ja uskonnon kaksi alkuperää, 1932) ja esittää, että nauru palvelee Bergsonin analyysissa konservatiivista, "suljettua" yhteisöllistä moraalia. Näin ollen nauru näyttäisi yhteisöllisessä tehtävässään kääntyvän alkuperäistä tehtäväänsä vastaan. Bergsonin mukaan naurun perustehtävä on nimittäin elinvoiman turvaaminen, mutta osana inhimillistä kulttuuria naurusta onkin vähitellen tullut yhteisön normien vahtikoira. Runoilija Jean-Baptiste de Santeulin sanoin castigat ridendo mores - komedia oikaisee tapoja nauraen. Voiko tätä moralistista naurua mitenkään erottaa elinvoimaisesta naurusta? Millä perusteella näennäisesti sama toiminto olisi perustavammalla tasolla elämän luovuuden puolella ja pinnallisemmalla tasolla myös sitä vastaan? Bergsonin analyysin perusteella vaikuttaisi siltä, että joko nauru ei ole yhtenäinen ilmiö tai sitten se ei ole yksiselitteisesti luovuuden eikä totunnaisuudenkaan puolella.

Nähdäkseni Bergsonin perusajatusta onkin korjattava seuraavalla tavalla: nauru ei ole elämän yksinkertainen reaktio sitä rajoittavia taipumuksia kohtaan vaan nauru ainoastaan ilmentää tätä elinvoiman ja kangistumisen välistä jännitettä sellaisenaan, puolia valitsematta. Tämä on nähdäkseni Deleuzen intensiivisen huumorikäsityksen keskeisin sovellus: koominen jännite ei tyhjenny kahden voiman (joustavuuden ja jäykkyyden) vastakkaisuuteen ja kamppailuun, vaan jännite on itsessään todellinen ja aistittava ilmiö, liikkeelle paneva voima. Niinpä kumpikaan jännitteen navoista - joustavuus ja kankeus - ei ole perustavampi kuin toinen. Jännite on kuitenkin epäsymmetrinen ja näyttäytyy eri tavoin riippuen siitä, kummasta päädystä löydämme itsemme; näemmekö ympärillämme jotakin huvittavaa vai olemmeko itse naurettavia. Bergsonin analyysissa hämärtyy se seikka, että kankeus ei ole elämän ulkopuolelta tuleva uhka, vaan osa elämää, ainoastaan sen hitaampi ja vaimeampi muoto. Niin biologiset kuin yhteisöllisetkin tottumukset ohjaavat vähentämään toiminnan monipuolisuutta ja vaihtelevuutta mutta ovat kuitenkin aina enemmän tai vähemmän alttiina poikkeamille ja muutoksille. Muutos ja mukautuminen ovat vain tottumus- 
ten avoimempia, kiihdytettyjä muotoja, joiden myötä tottumukset menettävät, usein kivuliaastikin, vanhoja piirteitään omaksuakseen uusia.

Kun tarkastelemme luovuuden ja jäykkyyden välistä jännitettä sellaisenaan, voimme ymmärtää naurun luonteen kokonaisvaltaisemmin, rajoittumatta komediayleisön näkökulmaan. Joustavuuden ja kankeuden välisen jännitteen sijoittaminen naurun ytimeen on yhteensopivaa sen kanssa, että nauru voi ilmentää niin elinvoiman tunnetta kuin kyvyttömyydenkin tunnetta, nauru voi olla ihastunutta mutta myös vaivautunutta. Näin myös ratkeaa se epäsuhta Bergsonin teoriassa, että vaikka hänen mukaansa naurammekin jäykkyydelle, koomikon hauskuus päinvastoin perustuu hyvälle tilannetajulle ja ajoitukselle, jotka tuntuisivat olevan juuri elinvoimaisen luovuuden ja mukautuvuuden tunnusmerkkejä. Vastaavasti tuntuisi, että etäinenkin aavistus koomikon älystä ja taidosta pikemminkin lisää hauskuutta kuin vähentää sitä.

Bergson käsittelee hienovaraisesti koomikon taidetta ja eri tapoja, joilla koominen tilanne saadaan viritettyä, mutta naurua hän tarkastelee vain naiivin katsojan näkökulmasta: koominen tilanne kadulla naurattaa yhtä lailla kuin teatterissa, jonka komiikka on vain kärjistetympää ja pelkistetympää (Bergson 1994, 51). Lisäksi hän esittää hypoteesin, jonka mukaan nauramisen pelisäännöt opitaan olennaisilta osin jo lapsena, ja nauru palauttaa meidät näiden varhaisten kokemusten äärelle. Komiikan ja naurun pinnallisuus tuntuisi kuitenkin olevan ristiriidassa niiden oletetun moralismin kanssa. Bergsonin analyysin mukaan nauru on nimittäin perustavasti pinnallinen vastareaktio kankeuteen, ja tämä vastareaktio on valjastettu yhteisön yhdenmukaisuuden ja moraalin palvelukseen. Naurun pinnallisuudesta kuitenkin näyttäisi myös seuraavan, että mikään ei sido naurua tähän moraalin vartijan tehtävään vaan se voi myös kääntyä moraalin rajoittavuutta vastaan. Näin nauru Bergsonin kuvaaman perusluonteensa mukaisesti myös todennäköisesti tekee.

Väitän, että pinnallisuudestaan huolimatta nauru kuitenkin kytkeytyy perustavasti koomiseen jännitteeseen, mutta ikään kuin riippumattomana. Mistä naurun kohde sitten riippuu, jos se ei palvele mitään yksittäistä tarkoitusta? Koomisen jännitteen huomaaminen tuntuisi riittävän kirvoittamaan naurut. Tämä on myös mahdollinen selitys naurun tarttuvuudelle ja taustanaurun toimivuudelle, sillä toisten nauru ikään kuin herättelee huomaamaan tilanteen koomisuuden, sen korostuneen jäykän aineksen.

Bergsonin tunnistama jännite kankeuden ja joustavan mukautuvuuden välillä vaikuttaisi siis olevan perustava naurun kannalta. Hän kuitenkin kytkee naurun myös yhteiskunnan yhdenmukaistavaan moralismiin, joka taas on potentiaalisesti yhtä jähmettävä taipumus kuin yksittäiset näennäisen jähmeät poikkeamat, joita se ryhtyy korjaamaan. Bergson siis sitoo naurun liian tiukasti yhteisön elinvoimaisuuden puolustamiseen, ja sitä kautta myös rajoittavaan moralismiin. Mutta voisiko koomisella jännitteellä olla myös vapauttavia vaikutuksia?

\section{Spinozan ja Nietzschen iloinen nauru}

Bergson määrittelee ensin naurun elinvoiman ilmaisuna, mutta tarkemmassa analyysissa nauru näyttäytyykin pikemminkin yhteisön yhdenmukaisuuden hienovaraisen pisteliäänä vartijana. Olen esittänyt, että nämä naurun eri muodot tulevat ymmärrettäviksi vain jos naurun nähdään ilmentävän koomista jännitettä sellaisenaan, eikä vain sen jompaakumpaa ääripäätä. On kuitenkin vielä jäänyt selvittämättä, onko naurulla jokin aidosti vapauttava tai rakentava tehtävä. Bergsonkin puhuu naurun iloista ja mielihyvästä (plaisir), mutta hän tuntuu olettavan tämän mielihyvän olevan yhteisön elinvoiman palveluksessa. Niinpä naurun miellyttävyys kulkee analyysin mukana eräänlaisena taustaoletuksena ja lapsuusmuistona. Loppujen lopuksi naurun miellyttävyys kuitenkin näyttäytyy pikemminkin valheellisena vaikutelmana, kun käy ilmi että komediassa ja komiikassa viime kädessä yhteisö aina nauraa yksilön kustannuksella. Mihin naurun alkuperäisempi elinvoimaisuus sitten voisi perustua ja mistä siihen kytkeytyvä mielihyvä ja ilo kumpuavat?

On syytä täydentää Bergsonin luovan elinvoimaisuuden näkökulmaa Baruch Spinozan toimintakyvyn analyysilla. Siinä missä Bergsonin ajat- 
telua voi luonnehtia luovuuden ja elinvoiman etiikaksi, Spinoza taas muotoili toimintakyvyn etiikkaa: minkälaiset kokemukset ja minkälainen toiminta edistävät toimintakykyä ja mikä heikentää sitä? Spinozan ilon määritelmä antaa jo osviittaa Bergsonin ja Spinozan filosofisesta kosketuspinnasta: ilo (laetitia) on toimintakyvyn voimistumista ja tietoisuutta tästä muutoksesta (Spinoza 1994, 147, 138; vrt. Deleuze 2012, 65). Spinoza tosin pitää naurua ensisijaisesti ruumiintoimintona, joka ei kytkeydy välttämättä mihinkään tiettyyn mielentilaan (Spinoza 1994, 187). Myöhemmin Etiikassa hän kuitenkin kytkee naurun suoraan iloon: "Sillä nauru on, kuten leikinlaskukin, puhdasta iloa ja näin siis sinänsä hyvää, kunhan ei käy liialliseksi” (mt. 239).

Spinozan empiminen naurun luonteen suhteen johtuu siitä, että nauru on ruumiillista, kun taas ilo on toimintakyvyn voimistumista samanaikaisesti niin henkisesti kuin ruumiillisestikin. Nauru voi siis säestää tätä voimistumista niin kauan kun ihminen ei jää sen vangiksi. Spinozan käsitteistössä liiallinen nauraminen merkitsisi passiivisuutta, jossa yksilö ei ole itse oman ajattelunsa ja toimintansa lähde, vaan geneeristen ulkoisten kaavamaisuuksien ja prosessien vallassa. Bergsonin komiikan analyysi käy tässä kohdin yksiin Spinozan käsitteistön kanssa: stereotyyppinen ja kaavoihin kangistunut koominen hahmo on passiivinen Spinozan mielessä, mekanismin vietävänä ja erossa kyvyistään. Toisaalta Spinoza huomauttaa, että nauru voi olla jopa välttämätön liittolainen mielen ja ruumiin itsenäistymisen ja voimistumisen tiellä. Mielen ja ajattelun itsenäisyys ei nimittäin tarkoita irrallisuutta ulottuvasta, aineellisesta todellisuudesta vaan päinvastoin ajattelukyky voi kehittyä ja voimistua vain suhteessa ympäröivään todellisuuteen ja rinnakkain ruumiin toimintakyvyn kehittyessä. (mt. 239-240.)

Filosofeista painokkaimmin naurun kytkee elinvoimaan ja elämänmyönteisyyteen tietysti Nietzsche. Deleuze muotoilee tämän siten, että "nauraminen on elämän myöntämistä ja jopa elämään sisältyvän kärsimyksen myöntämistä” (Deleuze 2005, 220). Nauru esiintyy Nietzschen Zarathustrassa osana leikin, naurun ja tanssin yli-inhimillistä kolminaisuutta: leikki myöntää sattuman, nauru elämän ja tanssi tulemisen. Näiden kepeiden hahmojen kautta Nietzsche luonnostelee tulevaisuuden ajattelua, joka ei takerru olemassaoleviin malleihin, olemuksiin ja maailmankuvaan vaan avautuu todellisuudelle luovasti.

Nietzscheläisen myöntämisen eli affirmoimisen, vahvistamisen ja kannustamisen kolmelle mallille on kaikille ominaista tietty jännite. Sattuma tuo mukanaan satunnaisen tapahtuman välttämättömyyden ja peruuttamattomuuden, elämä tuo mukanaan kärsimyksen ja tuleminen olemisen, jonkin kehkeytyvän olennon. (Deleuze 2005, 220-221; Nietzsche 1999a, 363-368) Tämä jännitteisyys on Nietzschen ajattelun ytimessä: arvoja ei voi vain korvata uusilla, ei edes dialektisesti sisällyttäen ne uusiin arvoihin, vaan uusi arvo voi erottautua vain muodostamalla konkreettisen ja jännitteisen etäisyyden aiempaan. Nauru siis Nietzschenkin mukaan tukee elinvoimaa, mutta ei kiellä tai torju kärsimystä eli elinvoiman vähenemistä. Sen sijaan nauru kohtaa elinvoiman jännitteessään kärsimyksen kanssa ja voi hyväksyä tämän jännitteen eri tavoin: nauru voi iloita kärsimyksen poistumisesta, se voi nauraa omien vaivojen vähäisyydelle, toisten jäykkyydelle, omalle jäykkyydelle. Elämän myöntämisen jännitteisen kaksinapaisuuden lisäksi nauru Deleuzen mukaan avautuu elämän moninaisuudelle (ks. Deleuze 2005, 30-32, 247-248, vrt. 14-16). Nähdäkseni tämä on juuri seurausta elinvoimaisuuden jännitteisyyden huomaamisesta ja hyväksymisestä eri asteineen ja muotoineen.

Paradoksaalisesti Nietzsche kuitenkin liittää iloisen elämän myöntämisen tragediaan. Tragedian päähenkilö on nimittäin Nietzschen mukaan olennaisesti avoin vaikeille olosuhteille ja kärsimykselle, ja tilanteen äärimmäisyys ei ole niinkään varoitus katsojalle tai yritys herättää tämän sääli kuin osoitus elämän moninaisuudesta: onnettomuudet ja kärsimykset eivät tule elämän ulkopuolelta vaan ne virittyvät osaksi elämän muita voimia. Niinpä traagista ei ole Nietzschen mukaan päähenkilön kärsimys vaan juuri päähenkilön ilo, kyky valita kohtalonsa. (Deleuze 2005, 30-32; Nietzsche 1999b, 555-556.)

Totesimme yllä Bergsonin ajattelun yhteydessä, että nauru ilmentää jännitettä mukautuvan 
elinvoiman ja sitä kangistavien voimien välillä, mutta että Bergsonin lähtöoletusten vastaisesti nauru ei loppujen lopuksi ole yksiselitteisesti kummankaan taipumuksen palveluksessa. Vastaavasti voimme tarkentaa Spinozan huomiota naurun ja ilon yhteydestä siten, että nauru ei ole pelkästään ilon mahdollinen kylkiäinen vaan hersyy aina jännitteestä toimintakyvyn voimistumisen ja kyvyttömyyden välillä. Tämä selittäisi sen, miksi sekä oma onnistuminen että epäonnistuminen voivat naurattaa. Deleuzen mukaan Nietzsche vie tämän elämän myöntämisen äärimmilleen liittämällä nauravan kepeyden traagiseen sankariin.

\section{Naurun ja tragedian väkinäisyys ja vapaus}

Koominen jännite purkautuu nauruna, mutta miksi tällainen jännite syntyy komediassa helposti mutta loistaa Bergsonin mukaan poissaolollaan tragediassa? Kuten yllä näimme, Bergsonin ensisijainen vastaus on "tunteiden hetkellinen puudutus", eli nauraessamme komiikalle suljemme pois yksilöä koskevan myötätunnon ja näemme hetkellisesti vain jäykän mekaanisuuden (Bergson 1994, 9-10). Mutta miten tällainen tunnepuudutus saadaan aikaiseksi? Vastaus löytyy yksilön suhteesta vapauteensa.

Bergson itse kytkee vapauden traagisuuteen ja mekaanisen väkinäisyyden koomisuuteen (mt. 59). Tässä olennaista on yksilön suhde omaan toimintaansa: traaginen yksilö on tietoinen omasta vapaudestaan (vaikka ei kykenekään vaikuttamaan tapahtumien kulkuun), koominen yksilö taas on kaavamaisten mekanismien vallassa. Bergsonin mukaan vapaus täytyy ymmärtää yksilön kykynä toteuttaa ominaisimpia ja ainutkertaisimpia taipumuksiaan ja kykyjään (Bergson 2013a, 127-131, 181). Koominen hahmo elää tukevasti arkisten kaavamaisuuksien maailmassa. Traaginen yksilö taas on Bergsonin näkökulmasta vapaa, sikäli kuin traagiset kokemukset määrittävät häntä yksilönä ja hän on täysin tietoinen niistä. Bergson tuleekin yllättävän lähelle Nietzschen tragediakäsitystä: traagista on perustava avoimuus tilanteen vaikutuksille. Lisäksi taiteilija kehittää traagisessa hahmossa monimutkaisia ja vaarallisia taipumuk- sia, joita hän ei itse ole kokenut, mutta jotka hän kuitenkin löytää itsestään ikään kuin ituina:

Kirjailijan luova mielikuvitus voi olla vain pidemmälle viety näkemys todellisuudesta. Kirjailijan luomat henkilöhahmot antavat eloisan vaikutelman vain siksi, että ne ovat kirjailijan itsensä jatkeita. Hahmoissaan kirjailija syventyy itseensä niin keskittyneesti, että hän tavoittaa todellisuudessa piilevän mahdollisuuden [le virtuel], ja viimeistelee sen, minkä luonto jätti hänessä luonnoksen tai pelkän suunnitelman asteelle. (Bergson 1994, 119, suomennosta muokattu.)

Näytelmäkirjailija siis ikään kuin luo tragedioissa ja draamoissa vaihtoehtoisia elämiä itselleen, mutta näiden uskottavuus ja koskettavuus ei perustu Bergsonin mukaan niiden yleisinhimillisyyteen vaan päinvastoin niiden yksilöllisyyteen ja ainutkertaisuuteen, jota kirjailija kehittelee mahdollisimman rohkeasti ja monipuolisesti.

Siinä missä vapaus on kosketuksissa elämän ainutkertaisuuden ja yksilöllisyyden kanssa, Bergsonin mukaan koomisuus taas perustuu vain yleisiin muotteihin, stereotypioihin ja mekaanisuuteen ja on siis epävapaata. Nähdäkseni kuitenkin hajamielisyys ja poissaolevuus on koomista vain sitä taustaa vasten, että koominen yksilö voisi toimia toisin, eli että hän on kuitenkin perustavasti vapaa. Bergson itse ilmaisee tämän siten, että koominen mekaanisuus on mekanismia elämän luovuuden piirissä, eli mekaanisuus ei itsessään ole huvittavaa. Ja vaikka hyväksyisimme Bergsonin vapauden määritelmän, vapaus ei kuitenkaan välttämättä ole traagista, ja tragedian traagisuus edellyttää yksilön vapauden ja valppauden lisäksi sitä, että tämä ei kuitenkaan kykene vaikuttamaan tapahtumien kulkuun. Toisin sanoen koomisen hahmon ja traagisen yksilön ero ei selity pelkästään yhden mekaanisuudella ja toisen vapaudella, paitsi sikäli kuin tämä erottelu tehdään suhteessa tietoisuuteen ja valppauteen. Traaginen yksilö on tietoinen vapaudestaan, koominen hahmo taas ei. Vastaavasti traagisen yksilön väkinäiset rajoitteet tulevat ulkoapäin, koomisen hahmon taas sisältä, tämän omasta hairahtumisesta.

Naurun kepeys kytkeytyy Bergsonin analyy- 
seissa myös perustavaan turvallisuuden tunteeseen. Ensinnäkin Bergsonin mukaan koominen nauru ilmaantuu kulttuuriin eräänlaisena hienovaraisena yhteisöllisenä näpäytyksenä sopeutumattomalle yksilölle. Komedian olemassaolo kertoo jokseenkin edistyneestä kulttuurista, jossa elämän perustarpeiden sijaan voidaan keskittyä yhteisöllisen koheesion hienovaraiseen virittämiseen. Bergsonilla on tässä selvästikin mielessä antiikin Kreikka komedioineen: kun yhteiskunnan elinehdot on saatu turvattua, voidaan keskittyä yhteiselon sopusointuisuuden täydellistämiseen erilaisten yhteisöllisten rituaalien ja taiteiden kautta. Sopeutumattomuus ei useimmiten muodosta todellista uhkaa yhteisön turvallisuudelle, mutta mutta vakavamman uhan puuttuessa yhteisö aina kanavoi itsesuojeluvaistonsa johonkin epäkohtaan. Väkivaltainen reaktio vähäiseen poikkeavuuteen kuitenkin häiritsisi rauhaisaa yhteiseloa entistä enemmän, ja niinpä nauru on Bergsonin mukaan valikoitunut ihanteelliseksi ojentamisvälineeksi: se kiinnittää huomion kankeuteen ja nöyryyttää, mutta vain kepeästi ja aiheuttamatta pysyvää vahinkoa.

[Yhteiskunta] kohtaa jotakin levottomuutta herättävää, joka kuitenkin näyttäytyy pelkkänä oireena jostakin muusta - kyseessä ei ole varsinainen uhka vaan pelkkä ele. Niinpä yhteiskunta myös vastaa pelkällä eleellä. Nauru on epäilemättä jotakin tämänkaltaista, eräänlainen yhteisöllinen ele. Se tukahduttaa poikkeavuudet kylvämällä pelkoa; se herättelee ja pitää yhteyttä toisarvoisiin toiminnanmuotoihin, jotka ovat vaarassa eristäytyä ja hiipua; se pehmentää viimeisetkin mekaanisen jäykkyyden rippeet yhteiskunnan kokonaisuudesta. (Bergson 1994, 19-20, suomennosta muokattu; vrt. 97.)

Nauru siis edellyttää turvallisuuden tunnetta: naurun kohteena oleva kankeus on uhka, josta kuitenkin voidaan selvitä pisteliäällä huomautuksella. Turvallisuuden tunne ulottuu myös naurun kohteeseen, eli koominen hahmo itse ei vaikuta olevan vaarassa. Turvallisuuden tunne kytkeytyykin selvästi vapauden ja vaihtoehtojen horisonttiin: vastoinkäyminen voi näyttäytyä koomisena, jos siihen on voinut vapaasti vaikuttaa ja sen seu- raukset eivät ole lopullisia.

Mikäli komiikka on turvallisen harmitonta, perustuisiko tragedia valinnanvapauden puutteeseen ja seurausten peruuttamattomuuteen? Nietzsche kuitenkin peräänkuuluttaa tragediaan taitelijan myöntävää näkökulmaa kriitikon huonon omatunnon sijaan. Tragedian ydin ei siis ole hänen mukaansa yleisön vaikutelmissa ja reaktioissa vaan traagisen hahmon ajatus- ja kokemusmaailmassa, jonka satunnaisuuden ja välttämättömyyden välisen jännitteen taiteilija myöntää ja ilmaisee teoksessa. Kuten jo totesimme, Bergson liittää traagisen vapauden yksilön välittömän tiedostavaan näkökulmaan. (Bergson 1994, 59). Lisäksi tragedia ja draama mahdollistavat perustavien, väkivaltaistenkin jännitteiden kokemisen:

Varmastikin tämän kahtalaisen vaikutuksen ansiosta ihmissuvulle on kehittynyt pintakerros tunteista ja ajatuksista, jotka vastustavat muutosta, jotka pyrkivät olemaan yhteiset kaikille, ja jotka peittävät, silloin kun niiden voima ei riitä tukahduttamaan, yksilökohtaisten intohimojen sisäisen tulen. Ihmiskunnan hidas edistyminen kohti yhä rauhallisempaa yhteiselämää on vähitellen lujittanut tuota kerrosta, samalla tavoin kuin planeettammekin elämä on ollut pitkää ponnistelua kylmän ja kiinteän kuoren luomiseksi kiehuvien metallien tulisille massoille. Mutta tuliperäisiä purkauksia syntyy silti. Ja jos maapallo olisi elävä olio, kuten mytologia esittää, se kenties levätessään mielellään uneksisi noista rajuista räjähdyksistä, joissa se yhtäkkiä tavoittaisi syvällisimmän itsensä. Tämänkaltaisen nautinnon draama meille tarjoaa. Sen rauhallisen ja porvarillisen elämän alla, jonka yhteiskunta ja järki ovat meille laatineet, se pistää meissä liikkeeseen jotakin, mikä onneksi ei purkaudu, mutta joka saa meidät tuntemaan sisäiset jännitteemme. Draamassa luonto kostaa yhteiskunnalle. [...] Mutta kummassakin tapauksessa, riippumatta siitä heikentääkö draama yhteiskuntaa vai voimistaako se luontoa, sen tavoite on sama; paljastaa meille kätketty osa itseämme, jota voitaisiin kutsua persoonallisuutemme traagiseksi tekijäksi. (mt. 113-114.)

Bergsonin mukaan tragedia ja draama siis vapauttavat elämän jännitteisiä ja kumouksellisia 
voimia. Vapautuneisuudestaan huolimatta Bergsonin traaginen yksilö pysyy kuitenkin vakavana. Nietzsche taas nimenomaan näkee traagisen jännitteisyyden hyväksymisen iloisena ja nauravana. Tämä tulee ymmärrettäväksi, kun huomaamme että nauru kumpuaa koomisesta jännitteestä joustavuuden ja kankeuden tai elinvoiman ja voimattomuuden välillä, ja vastaavasti näennäisen kielteisistä asioista voi tulla naurun ja ilon aiheita kun ne myönnetään jännitteisissä suhteissaan.

\section{Lopuksi}

Nauru kytkeytyy vapauden tunteeseen, mutta kielii myös aina ihmisen äärellisyydestä: Bergson esittää, että jos kykenisimme olemaan täysin hereillä todellisuuden tapahtumille ja mukautumaan niihin välittömästi, emme tarvitsisi taidetta näyttämään meille todellisuuden kätkeytyneitä puolia emmekä naurua herättämään meitä jähmettyneistä tottumuksistamme. Antiikista alkaen nauru onkin nähty ihmisen puutteellisuuden ilmentymänä: pilkallisena ylimielisyytenä ja luonteenheikkoutena, joka vaimentaa järjen äänen. Platonin ihannevaltiossa ei sopinutkaan nauraa. Äärellisyyttä ei kuitenkaan pitäisi sekoittaa puuteellisuuteen, joka olisi periaatteessa korjattavissa. Bergson vaihtaa omaperäisesti näkökulmaa ruumiillisuuden ja järjellisyyden välisestä kahtiajaosta elämän piiriin kuuluvaan jännitteeseen kankeuden ja joustavuuden välillä, jotka valtaavat sekä mielen että ruumiin (Worms 2009, 24).

Nauru huomaa kuitenkin vain välittömän kankeuden ja jäykkyyden. Välittömyydestä johtuen se ei huomaa syvälle juurtunutta kankeutta, ja tämän esiin tuomiseksi tarvitaan Bergsonin mukaan komiikkaa. Lisäksi nauru voi pinnallisuudestaan johtuen kohdistua täysin vastakkaisiin jäykkyyden muotoihin.

Tarkastelumme tuki Bergsonin pääoivallusta naurun luonteesta joustavan elinvoimaisuuden ja kankeuden välisen, koomisen jännitteen ilmaisijana. Lisäksi Bergsonin teoriaa tavoittaa naurun yhteisöllisen dynamiikan näkökulman. Teorian keskeisenä puutteena on kuitenkin se, että vaikka nauru on Bergsonin mukaan viime kädessä pinnal- lista ja puolueetonta, hän näkee sen kuitenkin lähtökohtaisesti elinvoiman puolustajana. Tällä perusteella hän liittää nauruun myös yhteiskunnan yhdenmukaisuuden ylläpitäjän roolin. Naurun pinnallisuutta ja puolueellisuutta koskeva dilemma ratkeaa, kun huomataan naurun ilmaisevan suoraan jännitteen elinvoiman ja kankeuden välillä tai toimintakyvyn voimistumisen ja kyvyttömyyden välillä. Tällöin naurua ei itsessään ole sidottu jännitteen kumpaankaan napaan. Koomisen jännitteen voi siis nähdä deleuzeläisenä intensiteettinä, jännite- tai potentiaalierona tai etäisyytenä.

Spinoza puolestaan kuvaa naurua toimintakyvyn kasvun iloisena ilmauksena, joka ei kuitenkaan puolusta elinvoimaa ulkoista mekaanisuutta vastaan vaan erottautuu yksilön aiemmasta, jähmeämmästä tilasta. Naurun monimuotoinen ja paradoksaalinen jännitteisyys tulee kuitenkin kenties vielä selvemmin esiin Nietzschellä, jolla nauru ilmentää elämän jännitteisyyden affirmointia eli myöntämistä nautintoineen ja kärsimyksineen. Sikäli kuin todellisuus saattaa meidät yhä uudenlaisiin tilanteisiin, koominen jännite mukautuvan joustavuuden ja totunnaisen jämähtämisen välillä syntyykin yhä uudestaan ja antaa aihetta nauruun.

FT JULIUS TELIVUO on tutkijatohtori Jyväskylän yliopiston Yhteiskuntatieteiden ja filosofian laitoksella.

\section{VIITTEET}

1 Bergsonin maine kantautui 1900-luvun alkupuolella Suomeen asti ja maan johtavat filosofit Eino Kaila sekä Erik Ahlman kirjoittivat kummatkin Bergsonin filosofiasta - ja nimenomaan teoksesta Nauru. Kuherruskuukausi ranskalaisen filosofian kanssa kuitenkin päättyi 1920-luvulla, jolloin Suomen filosofinen keskustelu siirtyi vähitellen Wienin piirin ja analyyttisen filosofian vaikutuspiiriin. Muutos näkyy hyvin selvästi Kailan kirjoituksissa, joista tuli tämän jälkeen yhä loogis-empiristisempiä. Ahlman taas säilytti avaramman näkökulman filosofiaan ja sen mahdollisiin aiheisiin kirjoittaen kulttuurifilosofiasta ja filosofisesta antropologiasta. Bergsonin sijaan Ahlmanin ajattelua innoittivat kuitenkin erityisesti saksankieliset filosofit kuten Schopenhauer ja Scheler. 
2 Teatteriohjaaja Peter Hall on huomauttanut, että Oscar Wilden näytelmien sutkautukset ja paradoksit eivät ole pelkkää näppärää sanahelinää, vaan ne ilmentävät aina tunnelatauksen voimistumista, intensiteettiä. Wildelainen paradoksi yllättää ja naurattaa, mutta se myös kiteyttää tilanteeseen sisältyvän jännitteen. Wildelaiset paradoksit eivät siis ole itsenäisiä nokkeluuksia vaan osa kohtauksen jännitteistä kehittelyä ja rytmitystä.

3 Spinozan rationalistinen ajattelun riippumattomuuden ja järjen jumalaisuuden korostaminen on usein tulkittu suppeasti siten, että eiulottuvaisen mielen erillisyys ulottuvaisesta ruumiista merkitsisi myös irrallisuutta, ikään kuin yksilö voisi vain päättää sulkeutua aistien ja ruumiin ärsykkeiltä ja tuntemuksilta ja näin saavuttaa mielenrauhan. Tosiasiassa spinozalainen yksilö on väistämättä ja jatkuvasti uppoutuneena aineelliseen todellisuuteen ja reagoi sen vaikutuksiin. Tässä asetelmassa yksilö voi ainoastaan vähitellen pyrkiä toimintakykyä lisäävien vaikutusten piiriin ja tulla myös aktiivisemmaksi. Tämä aktivoituminen ja toimintakyvyn lisääntyminen tapahtuu kyllä mielen johdolla, mutta kytkeytyy aina ruumiin kykyjen voimistumiseen ja moninaistumiseen.

\section{KIRJALLISUUS}

Alhanen, Kai (2010) "Bergson nauraa yhä". Teoksessa Timo Miettinen, Simo Pulkkinen ja Joona Taipale (toim.) Fenomenologian ydinkysymyksiä. Gaudeamus, Helsinki.

Astesiano, Lionel (2016) Joie et liberté chez Bergson et Spinoza. CNRS éditions, Paris.

Bergson, Henri (1939) [1896] Matière et mémoire. Essai sur la relation du corps et de l'esprit. Presses Universitaires de France, Paris.

Bergson, Henri (1994) Nauru. Tutkimus koomisen merkityksestä (Le rire. Essai sur la signification du comique). Suom. Sanna Isto ja Marko Pasanen. Lokikirjat, Helsinki.

Bergson, H. (2007) [1907] L'Évolution créatrice, Presses Universitaires de France, Paris.

Bergson, Henri (2012) [1900] Le rire. Essai sur la signification du comique. Presses Universitaires de France, Paris.

Bergson, Henri (2013a) [1889] Essai sur les données immédiates de la conscience. Presses Universitaires de France, Paris.

Bergson, Henri (2013b) [1932] Les Deux Sources de la morale et de la religion. Presses Universitaires de France, Paris.
Critchley, Simon (2006) On Humour, Routledge.

Deleuze, Gilles (2018) Bergsonismi (Le bergsonisme). Suom. Eetu Viren. Tutkijaliitto, Helsinki.

Deleuze, Gilles (1968) Différence et répétition. Presses universitaires de France, Paris.

Deleuze, Gilles (2012) Spinoza. Käytännöllinen filosofia (Spinoza. Philosophie pratique). Suom. Eetu Viren. Tutkijaliitto, Helsinki.

Deleuze, Gilles (1985) Cinéma 2. L’Image-temps. Les Éditions de Minuit, Paris.

Deleuze, Gilles (2005) [1962] Nietzsche ja filosofia (Nietzsche et la philosophie). Suom. Tapani Kilpeläinen. Summa, Helsinki.

Eastman, Max, (1936) Enjoyment of Laughter. Halcyon House, New York.

Jankélévitch, Vladimir (1959) Henri Bergson. Presses Universitaires de France, Paris.

Kunnas, Tarmo (2017) Nietzsches Lachen. Eine Studie über das Komische bei Nietzsche. Brienna Verlag, Achenmühle.

Lehrer, Jonah (2011) Proust Was a Neuroscientist. Canongate, Edinburgh.

Morreall, John (2020) "Philosophy of Humor", The Stanford Encyclopedia of Philosophy (Fall 2020 Edition), Edward N. Zalta (ed.), URL = <https://plato.stanford. edu/archives/fall2020/entries/humor/>.

Nietzsche, Friedrich (1999a) Sämtliche Werke Kritische Studienausgabe in 15 Bänden, Band 4: Also sprach Zarathustra. Toim. G. Colli, M. Montinari. De Gruyter, Berlin.

Nietzsche, Friedrich (1999b) Sämtliche Werke Kritische Studienausgabe in 15 Bänden, Band 12: Nachgelassene Fragmente 1885-1887. Toim. G. Colli, M. Montinari. De Gruyter, Berlin.

Provine, Robert B. (2000) Laughter. A Scientific Invetigation. Viking, New York.

Prusak, Bernard G. (2004) "Le rire à nouveau: Rereading Bergson". The Journal of Aesthetics and Art Criticism, Vol. 62, No. 4, 377-388.

Sibertin-Blanc, Guillaume (2011) "Le rire comme fait social total (éléments de sociologie bergsonienne)". Teoksessa Frédéric Worms ja Camille Riquier (toim.) Lire Bergson, toim. F. Worms, C. Riquier. Presses Universitaires de France, Paris, 61-80.

Spinoza, Benedictus de (1994) Etiikka. Suom. Vesa Oittinen. Gaudamus, Helsinki.

Worms, Frédéric (2009) La philosophie en France au XXe siècle : Moments. Gallimard, Paris. 